\title{
Editor-in-Chief's Note
}

\section{ABOUT ISSUE 1 OF 2022}

his is the first issue of Access to Justice in Eastern Europe in 2022 and I am delighted to present our authors' contributions. This year is marked with a few very important events we are going to celebrate 25 years since the ratification of the European Convention on Human Rights in 1997 and 10 years since the adoption of the Criminal Code of Ukraine. Special issues are an essential part of academic publishing, and in honour of these years we prepared a few very important and interesting collections joined by a single topic. These were issues related to 1) justice during the Covid-19 Pandemic ${ }^{1}$, 2) justice in Ukraine during the period of independence ${ }^{2}, 3$ ) on the Occasion of the 70th Anniversary of the European Convention on Human Rights $\left.{ }^{3}, 4\right)$ the special edition related to the development of Alternative Dispute Resolution development in Europe $e^{4}$. I am delighted to note the attention of readers to these issues and that the published results are widely discussed and used by academics. We are continuing to follow this tradition, and the AJEE special issue for this year will be announced soon.

The research articles section opens with the article related to a very important practical issue in procedural law and the theory of law - the division of cases into easy ones and hard ones. It seems that the digitalisation of justice may significantly impact this division because of the courts' decision-making processes in such cases. In this essay, the author examines whether the solutions proposed by legal positivism (such as applying syllogisms and precedents) are sufficient to deal with easy cases and what factors analysed by legal realists have an impact on judges when making decisions in hard cases. I am delighted to note that the study takes a broad approach, considering psychological factors, such as hindsight bias, intuition, hunches, the anchor effect, laziness, unwillingness to take responsibility, or the gambler's fallacy, as well as social factors, like upbringing, life experience, social relations, gender, age, education, etc. I would support the author's conclusions that 'easy cases should eventually be delegated to artificial intelligence to resolve, whereas hard cases will remain in the competence of human judges, at least until technological development reaches a certain level' and admit that this is currently happening around us. Human beings continue to manage the 'hard' cases in all areas, while the 'easiest' are moved to digital tools, and this is spreading rapidly. Learn more about this topic and why and how these changes occur in the article of a young and promising researcher from Vilnius University, Goda Strikaité-Latušinskaja.

1 I Izarova About Special Double Issue 2-3/2020 "Justice under the Covid-19 Pandemic" 2020 2/3(7) Access to Justice in Eastern Europe 74-77.

2 I Izarova About Issue 3 of 2021 and the Evolution of Justice in Ukraine During the Period of Independence 2021 3(11) Access to Justice in Eastern Europe 5-7.

3 I Izarova, S Kravtsov 'About the Special Issue on the Occasion of the 70th Anniversary of the European Convention on Human Rights' 2021 1(9) Access to Justice in Eastern Europe 5-7. I Izarova About Special Issue in Access to Justice in Eastern Europe, 2019, Issue 3 (4), Pp. 4. 
A fresh and interesting perspective on derivative lawsuits and the right to file such a lawsuit was included in this issue. The regulation of derivative lawsuits differs in each jurisdiction, despite sharing common features, raising a variety of issues to be resolved. The author points out several issues and their possible solutions, which could be implemented in Ukrainian legislation. It is a great pleasure for me to highlight that the author Heorhii Smirnov is a postgraduate Student of our Law School at Taras Shevchenko National University of Kyiv.

An excellent study related to land rights disputes and the effective protection of rights was prepared by Oleh Ilnytslyi and Ivan Boychenyk. The choice of an effective and appropriate method of protection is one of the most important stages of legal proceedings because it determines the achievement of the proceedings' goal. Procedural legislation and the practice of its application to unresolved issues have limited methods of protection in cases of the rights and interests of persons to land by courts of different jurisdictions and limited possibilities for cross-application. I highly recommend reading this article to discover more about how procedural legislation and the practice of its application to unresolved issues have limited methods of protection in cases of the rights and interests of persons to land by courts of different jurisdictions and the possibility of their cross-application in Ukraine.

I also particularly want to draw the attention of our readers to the very interesting and inspiring note prepared by Dobrosława Szumiło-Kulczycka from Jagiellonian University as part of the 'Costs of a Criminal Trial in View of an Economic Analysis of Law' project. In her article, prof. Szumiło-Kulczycka points out three fundamental factors determining the amount of the expenses, i.e., the fact of the accused being imprisoned during the proceedings, the use of scientific evidence (opinions produced by expert witnesses), and the participation of a public defender remunerated by the State Treasury.

Joanna Bodio's review on the book 'Implementation of the principle of the best interests of the child in mediation in matters concerning the exercise of parental authority and contacts', edited by Joanna Mucha, appears in our issue as well.

This monograph was prepared with the wide participation of colleagues from European states and focused on a very important goal - the thesis that in court proceedings in matters relating to a child and mediation in matters concerning the exercise of parental rights and contact with a child, the primary value to be protected should be the best interests of the child.

I would like to thank both of my colleagues - the reviewer and the editor of this excellent book - and sincerely hope that we will continue this promising and important research.

A few notes have also been included in this issue due to their interesting insights and importance for further research.

Finally, let me share our latest announcement.

At AJEE, we made Online First Articles so that we could publish articles online as soon as they are reviewed, accepted, edited, and corrected. In some cases, authors face publishing delays, even though their work is complete. Online First Articles helps to address this problem by making articles available as soon as they are ready.

From now on, articles that have been fully corrected and finalised will appear here, on our website, available for our readers to use and cite.

Please enjoy this immediate access to the latest high-quality content!

Editor-in-Chief

Prof. Iryna Izarova

Law School, Taras Shevchenko National University of Kyiv,

Ukraine 